
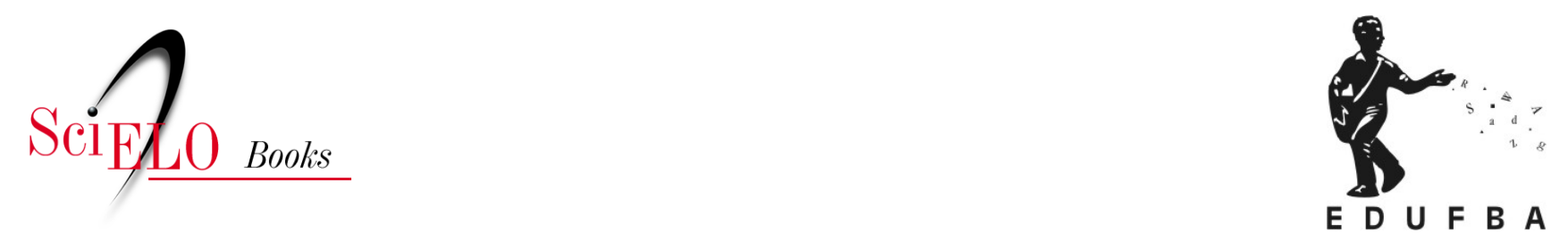

\title{
O uso do crack como ele é pesquisa observação participante entre usuários de crack
}

\author{
Ygor Diego Delgado Alves
}

\section{SciELO Books / SciELO Livros / SciELO Libros}

ALVES, Y.D.D. O uso do crack como ele é: pesquisa observação participante entre usuários de crack. In: Jamais fomos zumbis: contexto social e craqueiros na cidade de São Paulo [online]. Salvador: Edufba: Cetad, 2017, pp. 45-86. Drogas: clínica e cultura collection. ISBN: 978-85-232-1859-1. https://doi.org/10.7476/9788523218591.0004.

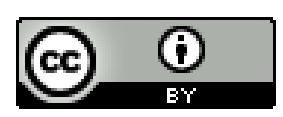

All the contents of this work, except where otherwise noted, is licensed under a Creative Commons Attribution $\underline{4.0 \text { International license. }}$

Todo o conteúdo deste trabalho, exceto quando houver ressalva, é publicado sob a licença Creative Commons Atribição 4.0. 


\section{O USO DO CRACK COMO ELE É: PESQUISA OBSERVAÇÃO PARTICIPANTE ENTRE USUÁRIOS DE CRACK}

"Porque a pedra, ela só... ela abre caminho.” ${ }^{21}$

No presente capítulo será discutido não só os dilemas éticos, mas também as dificuldades operacionais do trabalho de campo entre usuários de crack na região central de cidade de São Paulo. Para isso, nos valemos de descrições das atividades de pesquisa retiradas de cadernos de campo e sua posterior análise, a partir da literatura sobre metodologia e ética da pesquisa.

A prática etnográfica baseia-se na pesquisa de campo com observação participante desde os primórdios da antropologia cultural. (BERNARD, 2008) Envolve aproximação e serve-se da observação e anotação de informações acerca da vida de pessoas capazes de se sentirem suficientemente confortáveis com a presença e proximidade do pesquisador. Além disso, permite certo tipo de conhecimento experimentado que possibilita uma fala convincente sobre o tema pesquisado a partir das entranhas do etnógrafo. Pode ser um depoimento sobre o consumo de ecstasy e uma noite inteira de dança em uma rave no Rio de Janeiro (ALMEIDA; EUGENIO, 2008), ou a respeito de se passar a mesma noite usando crack no centro de São Paulo. ${ }^{22}$ Cabe ressaltar que nem todo trabalho de campo é observação participante, mas toda observação participante é trabalho de campo, pois coloca o antropólogo onde a ação acontece e permite a coleta de dados como histórias de vida e a observação de comportamentos que podem ser, posteriormente, cotejadas com as verbalizações sobre eles. Pode-se participar de rituais e conver-

21 Salomão, usuário de crack na região do Cambuci.

22 Seria razoável esperar a atenção dos formuladores de políticas públicas sobre o tema das drogas a pesquisas qualitativas levadas a cabo sobre este tema, porém, isto, aparentemente, ainda não ocorre. 
sar sobre temas sensiveis, aprender o linguajar e experimentar um estilo de vida tanto quanto for possivel. É importante a capacidade de agir de modo a permitir o "fluir" do cotidiano ao seu redor, adquirir conhecimento necessário para saber quando rir e onde está a graça, assim como para fazer rir propositalmente. A observação participante consiste em imergir em uma cultura e aprender como sair desta imersão para intelectualizar a partir do que foi visto, escutado e experimentado; e depois, colocar tudo em perspectiva e escrever convincentemente. Portanto, os pesquisadores de campo são instrumentos de coleta de dados e de análise destes dados, aperfeiçoados pela prática. Trata-se de estar pessoalmente interessado nas ocorrências do local, inclusive fofocas, de apresentar-se de cada vez mais de acordo com o jeito nativo para acessar os detalhes da vida familiar, da preparação ou obtenção e consumo dos alimentos e da toalete, por exemplo. Ater-se às habilidades de manufatura, como, por exemplo, confeccionar o cachimbo de tragar o crack, analisar as querelas, as cenas de uso, fatos usualmente triviais, embora, muitas vezes dramáticos e sempre significativos.

Aparentemente, pelos relatos de experiências etnográficas, quanto mais vezes se é visto, menos preocupação se causa, até se tornar despercebido. Num ambiente de atividade proibida e perseguida, como o do uso crack, devido ao constante risco de investidas punitivas por parte da polícia, a recepção aos desconhecidos e a vigilância são atividades exercidas a partir de certos papéis, como o de "contenção" de determinada "biqueira”. Em uma "biqueira”, com possibilidade de permanência para socialização e consumo do crack, mesmo o desconhecido se apresentando acompanhado de antigo frequentador, ele será alvo da inquirição a respeito de suas credencias para lá estar. De quem é conhecido? Qual o seu propósito? O antropólogo descobrirá que o cardápio de motivos para se estar ali não é muito variado: ou irá adquirir droga e rapidamente se retirar, ou irá consumi-la no fumódromo. Caso não tenha papel acei- 
tável será imediatamente convidado a "fazer o peão", ou seja, retirar-se do local e só retornar caso possa se encaixar em algum papel aceitável.

As primeiras incursões ao campo foram realizadas na região do centro de São Paulo, conhecida como Cracolândia, nas tentativas iniciais, nem sequer foi possivel chegar ao local, demorando-se o pesquisador no reconhecimento dos arredores. Nas primeiras oportunidades de adentrar na cena de uso, observava-a, geralmente, a certa distância sem conseguir deter-me entre os usuários de crack. Foi encontrado um lugar de observação em um bar situado em frente a certo espaço utilizado para o consumo de crack. Lá, podiam-se beber garrafas de água e sentar-se ao balcão ou em uma das três mesas disponiveis, obter informações com os frequentadores e conversar com os usuários, presenças habituais no estabelecimento para comprar cigarros, isqueiro, salgados, além de presenciar a dificuldade destes para usar o banheiro. Foi possivel testemunhar o drama de uma usuária expulsa do bar; ao procurar saber do balconista as razões para esse tipo de tratamento, soube que se alguém não consome, não há como justificar seu uso do banheiro e o respectivo gasto com água. Pôde-se presenciar um pouco das dificuldades enfrentadas por mulheres usuárias para manterem a higiene na rua. Fora do bar, na calçada em frente, ou na rua, entre os usuários de crack, a situação não é tão diferente, caso não se esteja lá para fumar crack, não há como permanecer sem causar algum incômodo. Assim sendo, aos poucos, este pesquisador foi compondo um visual adequado à permanência e circulação na cena. Para Edward MacRae (2004), em uma situação de campo deve-se, na medida do crivel, livrar-se dos signos mais obstrutivos do trabalho. As vestimentas associadas à classe média coloca o antropólogo em situação pouco confortável e digna de suspeição no campo. ${ }^{23}$ A nova indumen-

23 Em suma: "faz parecer polícia", segundo os esclarecimentos dos usuários em mais de uma ocasião. 
tária foi composta por boné, propositalmente com inscrições do cantor Bob Marley, isqueiro adquirido quando da primeira tentativa de incursão, maço de cigarros e óculos escuros, estes últimos ajudariam, como pensado na época, a esconder o olhar curioso e de não usuário - com o tempo também se tornou possivel diferenciar o olhar e os olhos do usuário de crack. O fato de não ser usuário era também denunciado pelo sobrepeso, visivel principalmente na face, como revelado depois, ${ }^{24}$ isso tudo mudou ao sermos indicados a Newman. Voltamos a usar as vestimentas mencionadas somente quando retornarmos para fazer pesquisa de campo na Cracolândia. O contato foi feito por meio de dois colegas nossos do ensino médio, ambos haviam sido, assim como nós, usuários de drogas durante a juventude e o encontro com Newman foi marcado por telefone.

\section{Acessando d "biqueira"}

A fim de não se perder a dinâmica e fruição dos acontecimentos dados em campo, passo a transcrever os trechos das anotações de meu caderno. Por vezes, de modo intercalado, serão feitas as considerações analíticas possiveis. No entanto, é preciso fazer a ressalva sobre o momento da escrita destas anotações visto que era impossivel ir a campo e fazer as anotações in loco, devido ao fato de levantar-se suspeitas imediatas na Cracolândia, mesmo posicionando-se relativamente distante dos usuários, dentro de um bar. Fato idêntico ocorria nos lugares de uso frequentados com Newman e, por isso, as notas eram escritas após retorno do campo, juntamente com as transcrições das gravações, nos casos em que foi possivel utilizar o telefone celular para realizá-las, isto permitiu um processo rico de rememorar, elaborar

24 Também havia pouco tempo para a dedicação ao campo no início da pesquisa, visto que era entre o período do pesquisador deixar a filha na escola e retornar para buscá-la 4 horas e 30 minutos depois. 
e escrever. Os três trechos que seguem abaixo foram extraídos do caderno de campo em fevereiro de 2013:

Após revelar minha condição de pesquisador e a intenção de observar o uso da pedra, Newman propôs irmos a uma 'biqueira' pegar algumas e caberia a ele demonstrar como o crack é fumado. Este será o interlocutor-chave até eu começar a ir a campo por conta própria. Estávamos excitados com os propósitos científicos de nosso trabalho. A qualificação de que faziamos ciência serviu de justificativa do uso para Newman, que pretendia abandonar o hábito. ${ }^{25}$ Ao entrarmos no carro, teve início à 'correria' e o veículo já não era mais guiado como antes, tinha se transformado em uma espécie de viatura, pois estávamos em uma missão. Nós não nos confundiamos mais com os meros membros da classe trabalhadora deixados para trás no trânsito, não agíamos mais como 'caretas', haviamos passado para o outro lado ou, pelo menos, o antropólogo em pesquisa participante havia retornado para lá, após tantos anos. As regras de circulação de veículos já não se aplicavam mais inteiramente àquela situação.

Seguimos direto para a 'biqueira' localizada em uma planta de fábrica abandonada e ocupada, aparentemente, por familias da classe trabalhadora e do subproletariado. Ainda se encontra presente o antigo portão de metal da entrada dos caminhões, testemunha do periodo industrial do bairro; por este portão também se acessa a 'biqueira' a uns 50 metros adentro. Ao passarmos por bares na entrada, fomos encarados de modo ameaçador por dois homens, disto viria saber apenas em meu segundo encontro com Newman, pois o 'olhar de frango ${ }^{26}$ e de pesquisador novo no campo, não estava ainda suficientemente treinado para perceber muitos detalhes.

Passando os bares, avistamos o 'contenção' responsável por organizar os trabalhos, ele grita aos clientes para se apresentarem com as cédulas abertas na mão e levantarem a camiseta para mostrar a cintura livre de arma de

25 Vale esclarecer que após proporcionar à entrada no campo, Newman efetivamente parou de fumar crack, voltou a trabalhar como engenheiro e casou-se.

26 Termo utilizado para designar o usuário inexperiente, considerando-o como otário. 
fogo, além de terem de girar exibindo as costas, erguer a barra da calça para deixar visivel o tornozelo. Este mesmo rapaz, aparentando menos de 30 anos, indica-nos o local rente a uma parede em que devemos nos postar em fila. São umas oito horas da noite. Uns cinco clientes estão à nossa frente, em fila, encostados ao muro, e nos postamos atrás deles. Com o espaço de alguns segundos entre um e outro, novos compradores vão chegando e ficamos assistindo ao ritual de ser alertado, levantar a camisa, dar uma voltinha e levantar as barras das calças à chegada de cada novo usuário. O ambiente é um pouco tenso devido ao esforço contínuo do 'contenção' para manter um mínimo de concentração e 'procedimento' na fila de usuários. Não é tarefa fácil. A tendência à entropia é clara. Os enfileirados querem conversar e quebrar a atmosfera hostil. Fazem piadas, brincam, comentam o atendimento, contam breves casos, tentam alertar os outros sobre o perigo em tal ou qual lugar. Reclamam. Como se estivessem na agência bancária, protestam quando um comprador fura a fila. Exigem do 'contenção' a imposição da ordem na coisa toda. Este ameaça os que insistem em permanecer papeando: 'tô avisando, é pra ficar quieto, quem continuar falando vou mandar 'pro' fim da fila, depois não vem reclamar'. $O$ rapaz a furar a fila tem aparência de classe média, 'boy', isto joga mais combustivel nas reclamações. Aparece uma moça e é atendida preferencialmente, ela se oferece para comprar para alguém da fila masculina, ele aproveita a oportunidade para também furar, novos protestos. Depois ficariamos sabendo deste detalhe de procedimento de 'biqueira': são duas filas separadas por gênero e mulher tem preferência. Como na cadeia, as mulheres são extremamente respeitadas na 'biqueira': 'afinal de contas nunca se sabe se se estará mexendo com a mulher de alguém perigoso, ou não'; observou posteriormente Newman. Enfim, não é ambiente propício ao flerte amoroso.

O comportamento descrito nos três parágrafos acima, retirados do caderno de campo, corrobora com a descrição contida na tese de doutoramento de Lúcio Garcia de Oliveira a respeito da cultura do uso do crack na cidade de São Paulo:

Já no que se refere ao comércio em si, os entrevistados caracterizam-na como bastante organizada, relatando a 
formação de filas na bocada que funcionam sob regras rígidas. Além de mulher ter prioridade, as transações são rápidas, ou seja, se não há dinheiro ou não se aceita a proposta de venda, atende-se o próximo 'cliente' e assim por diante. (OLIVEIRA, 2007, p. 93)

$\mathrm{Na}$ referida tese, discorre-se sobre a organização da fila por diferença de gênero feita por um usuário com 29 anos de idade: [...] mulher não pega fila, às vezes tem fila, então, quando tem mulher eles passam na frente dos caras, que é uma lei, então homem nunca pega primeiro [...]. (OLIVEIRA, 2007, p. 93)

Os próximos dois trechos foram retirados do caderno de campo, em março de 2013, neles, se descreve o modo de aquisição das pedras de crack com seus procedimentos e alguns riscos ao pesquisador e interlocutor:

Chega a nossa vez e nosso interlocutor compra uma da menor correspondente a um papelote com crack. Entrega uma nota de vinte reais a um homem aparentando uns trinta anos, o qual segura com as duas mãos um saco plástico branco, do tipo dos usados em supermercado, que está cheio pela metade com papelotes de crack e de cocaina ou 'da maior'. Ele reclama um pouco por ter de dar troco, que é providenciado por um rapaz aparentemente menor de idade sentado em um banquinho de madeira com um bolo de notas na mão abertas em leque. Ele recebe a cédula de $R \$ 20,00$ passada pelo homem com a sacola contendo os papelotes e entrega o troco a meu interlocutor. Ao receber a droga se é imediatamente convidado a retirar-se do local. Saimos pelo mesmo caminho de entrada e paramos no bar próximo ao portão para comprar cigarros, mas as marcas de importados de baixa qualidade ali presentes não agradam meu interlocutor $e$ guia, dirigimo-nos para a calçada. Avistamos uma moça negra que, embora passasse a impressão de ser usuária, estava trabalhando para a 'biqueira' com um 'walk talk' em uma das mãos, igual ao visto na mão do 'contenção'. Voltamos à casa de meu interlocutor, onde haviamos nos encontrado pouco antes e presenciei o uso, recebi explicações e pude fotografar. 
Uma semana depois fomos os dois a outra 'biqueira', localizada em um bairro central de São Paulo. ${ }^{27}$ Avançamos por um corredor de não mais de vinte metros e encontramos dois homens com menos de trinta anos de idade que nos perguntaram quanta droga queríamos, Newman pediu duas 'da menor', ou seja, crack. Não há fila naquele horário, por instrução de meu informante parei o carro em uma rua lateral e não na rua da 'biqueira', cuidado que se revelou importante. Após sairmos e entrarmos em nosso veículo, dobramos na rua da 'biqueira' e seguimos sentido bairro, quando cruzamos com uma viatura de polícia dotada de 'side light' prontamente apontado no nosso rosto, possivelmente em busca de sinais de uso para abordagem - como ocorria naquele momento com uma dupla de jovens com aparência de classe média metros adiante - eles 'tomavam um enquadro', como nos explicou Newman, de dois policiais militares em outra viatura.

Os dois parágrafos retirados do caderno de campo e transcritos acima nos permitem pensar sobre este local de comércio de substâncias tornadas ilícitas e alteradoras do humor, a "biqueira". Ali, a repressão concentra-se no porte da droga pelo usuário enquanto a venda, ou tráfico, não é reprimida, pelo menos a ponto de fazê-lo cessar. O que poderia ser mais desmoralizante para uma política de repressão? Décadas de comércio em um mesmo imóvel? A óbvia associação da polícia ao tráfico? Afinal de contas, por que o ponto de venda não é fechado? Sequer necessita mudar de endereço, tem ponto fixo há 30 anos ou mais. Mas a resposta pode estar na possibilidade de ganhos por parte da polícia e esta possibilidade, certamente, se dá de forma diferente em relação ao traficante e ao usuário. Podemos conjecturar ser a abordagem ao usuário pela

27 É um ponto de venda de drogas ilicitas tradicional, conhecido não apenas por moradores da região, mas famoso em boa parte da cidade. Há tempos atrás, nos anos 1980, consistia em um portão de metal reforçado com uma janelinha por onde era recebido o dinheiro e entregue a droga. Este portão foi derrubado pela polícia com o uso de pesado ariete, informou Newman, crescido no bairro. O comércio passou a ser feito a partir de portão leve de grades com um adolescente dando a mesma instrução de entrar com o dinheiro aberto, visto na biqueira da semana anterior. 
polícia mais democrático, ou seja, à disposição dos policiais de plantão dispostos a permanecer nas proximidades da "biqueira" aguardando algum incauto ser pego ao acabar de adquirir seu pino de crack ou cocaína. Podemos, da mesma maneira, inferir a respeito do rateio do dinheiro obtido dos traficantes por parte da polícia para permanecerem exercendo sua atividade de modo ininterrupto durante décadas no mesmo local. Este deve "dar-se por cima", ou seja, acessivel apenas aos escalões mais elevados da polícia. O simples policial em busca de alguma substância para usar naquela noite e alguns trocados obtidos via chantagem sobre o usuário pego com certa quantidade de droga tem, provavelmente, na abordagem a granel sua motivação para rondar aquele espaço e as demais "biqueiras" da cidade prestando seu mau serviço à sociedade.

Newman chegou a descrever-nos um caso que aconteceu com ele e que ilustra certas relações possiveis entre policia, consumidores e traficantes em uma "biqueira". Certa vez, após adquirir alguma quantidade de drogas nesta tradicional "biqueira”, a que nos referimos anteriormente, ele se vê, juntamente com seu acompanhante, cercado por viaturas policiais. O carro que guiava no momento era particularmente propenso a este tipo de procedimento: um antigo modelo Ford tipo Maverick. Após ser parado para uma blitz - termo este retirado do alemão blitzkrieg, uma doutrina tática nazista. - Newman se viu na iminência de ser obrigado a contribuir financeiramente com os policiais que o haviam visto sair da do local e, certos dele estar de posse de algum "flagrante", esperavam receber seu quinhão. Não contavam eles com o fato de Newman ser antigo morador do bairro e velho freguês daquele ponto de venda. Isto motivou o "patrão da biqueira", imediatamente avisado da ação policial a poucas centenas de metros de seu estabelecimento comercial, a dirigir-se ao local da blitz e avisar os policiais que deveriam deixar aquele freguês em especial livre de sua ação predatória. No mesmo instante, segundo relato de meu interlocutor, ele se viu livre. 


\section{Participando de roda de crack em uma "biqueira"}

Conforme narrado, meu interlocutor e guia naquela noite e em algumas outras no decorrer do primeiro semestre de 2013 havia, juntamente comigo, comprado uma pedra em uma "biqueira” tradicional do bairro com décadas de funcionamento. Desse modo, seguimos como anotado no caderno de campo em março de 2013:

Passamos no caminho por uma terceira 'biqueira', na esperança de encontrarmos uma pedra e uma roda de crack, mas fomos informados do encerramento das atividades naquele local. Assim seguimos para outra dali a poucos metros, a 'biqueira' da Andressa, onde achariamos mais pedras e com quem usá-las. Caminhamos alguns metros por uma rua sem iluminação até o nosso destino. Ao chegar, dirigimo-nos a um conhecido de meu interlocutor e, após breve conversa, ele adentra pelo portão por onde logo entrariamos. Após receber nossos últimos $R \$ \$ 9,00$, quantidade insuficiente para adquirir uma pedra de $R \$ 10,00$, ele retorna com nossa encomendada. A falta de um real não foi problema devido à antiga relação entre os dois, meu interlocutor e este seu conhecido, também gerente do local. Foi-lhe perguntado se Amélia, irmã de Andressa, estaria lá e se poderíamos ir até ela. Prontamente nos foi autorizado.

Esta 'biqueira' localiza-se em um bairro na região central de São Paulo, o mesmo da 'Esta biqueira' visitada fazia pouco, em frente a um edificio sob a ocupação de sem tetos. Na entrada há um portão de metal no centro do muro à frente do terreno e ele possui, em seu interior, algumas casas. A passagem é feita por um corredor e como era noite, podem-se ver apenas as placas de madeira pelo chão sobre pedras e lama. Caminha-se ladeado por muros de outros barracos até o quarto que servirá de fumódromo, localizado após o que restou de outro cômodo derrubado, lá residem mãe e filha. A primeira chama-se Fabricia e a segunda Amélia. Ao chegarmos, apenas a última estava presente, acompanhada por Tide a quem chama carinhosamente de vó, elas fazem uso da pedra, mas no decorrer da noite outros usuários iriam aparecer. 
Ao chegar ao cômodo ${ }^{28}$ Newman foi saudado e cumprimentou Amélia com um abraço, o mesmo se dando com Tide. Fui apresentado inicialmente como primo de Newman e, em seguida, como antropólogo. Fui desqualificado como careta e isto causou certo embaraço em Amélia, ela aparentou sentir certo incômodo em usar em frente a um não usuário. Na tentativa de superar o constrangimento fui requalificado por Newman como ex-usuário de 'farinha', nome dado à cocaina aspirada e ex-interno de uma clínica de tratamento, prontamente manifestei-me sobre a minha condição de ex-usuário.

Figura 1 - "Fumaça. Sofra e morra!" -

Pichação na parede do quarto de Amélia

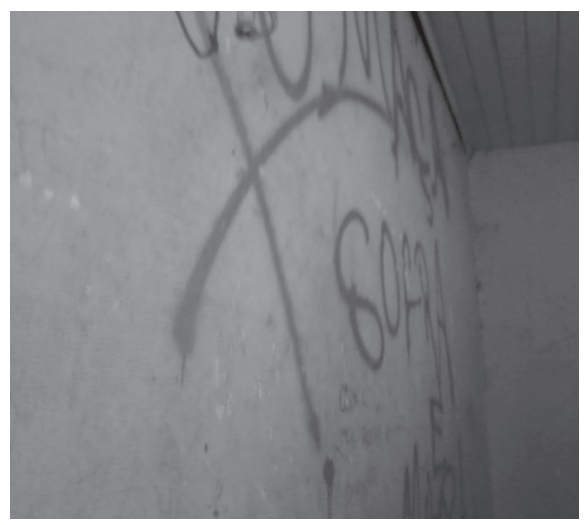

Fonte: Coleção pessoal do autor.

28 O quarto media uns $3 \times 3$ metros e estava com a terça parte coberto por roupas amontoadas que iam do colchão sobre o qual se sentava Amélia, no centro do cômodo, até a parede do fundo, chegando à altura de um metro de roupas entulhadas. Havia dois móveis baixos com aparência de balcão, ou partes de armários sobre os quais se sentava. Um deles coberto por um colchão de berço. Uma cristaleira me chamou a atenção pela beleza e cheguei a comentar com todos ali presentes da minha impressão, sendo informado de que não era o primeiro a reparar nessa qualidade do móvel. Uma parte de sofá vermelho desmembrado jazia em frente à porta, curiosamente virado com os assentos para esta. Poderia-se sentar em seu encosto ficando em uma altura não muito abaixo daqueles acomodados nos outros locais disponíveis, com exceção de Amélia localizada em um colchão de solteiro diretamente sobre o chão, na direção da porta, porém atrás do móvel com o colchão de berço, onde em breve viria se sentar Fabrícia. 
Importante comentar sobre este trecho do caderno de campo que acabo de reproduzir, que minha presença como não usuário era em si um constrangimento, só superável no futuro por uma postura mais próxima possivel do participante observador. A respeito do pudor revelado por Amélia em usar crack em minha presença, apenas tempos depois ficou claro pela pesquisa de campo um dos valores importantes entre usuários de crack: não fazer uso em frente ao "Zé povinho", ${ }^{29}$ ou não usuário. Não dar espaço para a maledicência, a crítica e o olhar reprovador, assim como não demonstrar ser desrespeitoso com os não usuários, os agredindo ao exibir o uso do crack. Retomando o caderno de campo pude perceber o clima de preocupação reinante no local:

\begin{abstract}
Existe um clima de apreensão com qualquer barulho associado à abertura do portão de acesso à rua, localizado a uns quinze metros de distância e ladeado, neste caminho, por outros barracos. Como é de metal faz barulho característico e em alto volume quando fechado com força. Qualquer sinal de presença de alguém de passagem a caminho do barraco localizado atrás ou ao lado do de Amélia e sua mãe também era digna de atenção e muitas vezes de comentário. Além de Amélia, sua mãe, Vó, Newman e eu, outros usuários ou não de crack se aproximaram e adentraram ao barraco. ${ }^{30}$ Amélia também vendia pedras tal qual sua irmã Vanessa fazia no barraco atrás daquele.
\end{abstract}

29 Termo utilizado para designar os não usuários de crack em atitude julgadora com relação aos craqueiros.

30 Um deles é um rapaz profissional de automação industrial, mas naquele momento estava desempregado. Ele e o engenheiro Newman conversam sobre assuntos técnicos, muito por iniciativa deste. O rapaz que aparenta menos de 30 anos de idade está com bom aspecto físico, não está magro, traja camisa preta, boné, calça jeans e óculos escuros. Estava do lado de fora, na rua, quando chegamos e lá o reencontrariamos quando de nossa ida embora. Nesta ocasião, ele estava acompanhado por uma moça e segundo Newman, usuária controlada de crack e garota de programa. Ela apareceu pela primeira vez justamente no momento de nossa saída para chamar Amélia até a rua. 
Nesta oportunidade, pude presenciar a avó de Amélia "brisando", assim como o uso por diversas pessoas, a roda de crack, o manejo da parafernália, a confecção de cachimbos, as exigências quanto ao comportamento adequado no local, os medos, a autoimagem dos usuários e as cobranças quanto a contribuir financeiramente para a manutenção da roda de crack.

\section{Frequentando uma "biqueira" com fumódromo a céu aberto 31}

Nos parágrafos a seguir, retirados do caderno de campo de abril de 2013, descrevemos os preparativos para, acompanhado de Newman, sair em busca de novos interlocutores em um local de uso com uma quantidade significativamente maior de usuários. Veremos como as hesitações e medos começaram a se dissipar conjuntamente com o maior contato com os usuários de crack.

Cerca de duas semanas após a visita à 'biqueira' de Amélia buscamos novamente Newman em sua casa, ele havia previamente alertado sobre o valor que deveria gastar aquela noite, estimando em $R \$$ 50,00. Alegou haver outros usuários que, provavelmente, estariam presentes em nossa roda, ele, possivelmente, calculou que a quantidade de cinco pedras fosse suficiente para o seu desejo de fumare os 'favorecimentos ${ }^{32}$ 'a fazer, mas não foi. Paramos antes em um bar. Disse-lhe para descermos do carro e tomarmos uma cerveja. Refletindo sobre o meu ato, vejo minhas

31 Não conseguia encontrar Newman na semana posterior a nossa visita à "biqueira" com fumódromo. Embora ele tivesse tentado me contatar, por causa de outros compromissos não pude ir. Ele queria, aparentemente, usar crack. Na semana seguinte, recebi uma espécie de ultimato para sairmos juntos porque ele estaria cogitando em não mais participar da pesquisa para dedicar-se a vida profissional. Ao encontrá-lo, mostrou-me uma sacola com roupas que havia lavado para uma usuária do fumódromo que eu iria conhecer naquela noite. Fiquei com a impressão, posteriormente, de que ele estava muito interessado em nosso encontro, avisou que iria "enfiar o pé na jaca".

32 "Favorecer" é o ato de fornecer parte do bloco, ou pedra de crack a outro usuário. O termo serve para demais artigos objeto de "treta", ou troca, em uma "biqueira". 
reiteradas tentativas para dar um 'ar de normalidade' ao que faziamos e iriamos fazer naquela noite ainda em seu inicio. Eram umas 19 horas 30 minutos, ele bebeu a cerveja rapidamente, compramos cigarro, isqueiro e tomei um energético para aguentar acordado. Aproveitei para ir ao banheiro, pois não existe no fumódromo. Fomos avisados ao chegar que o bar iria fechar em breve, explicamos, então, que sairiamos logo, para que fossemos servidos. Falávamos alto. Percebi um olhar diferente da balconista sobre nós, será? Saímos e resolvi retirar o lixo do carro, aproveitando uma lixeira que havia no poste ao lado. Queria deixar o veículo pronto e asseado para nossa 'balada'. Por quê? Isto dissolveria nossas intenções ilegais? O medo da pedra? Saimos.

No carro, Newman indicava o caminho à 'vapor', 33 pessoa que vende drogas em uma 'biqueira', ou seja, se ele não disser nada, é para seguir em frente, só se aponta os lados para onde se vira, uma economia de palavras $e$ de perguntas. 'Vou em frente?'A resposta seria: 'Por quê? Disse para virar?'. Estacionamos em frente a um bar do outro lado da rua com os faróis iluminando a 'biqueira' em frente. Mas ele quis me mostrar outra, a '29', no quarteirão abaixo. Fomos para lá. Ao chegarmos a um portão, sempre um portão, noto uma diferença entre a 'biqueira' de bairro e a de favela. Ao não se estabelecer a biqueira dentro de uma favela, ela necessita de separar-se da rua por porta de metal. Solidez material na falta de distanciamento social, isto também ocorre na 'biqueira' da rua Estudantes que viriamos a conhecer pouco tempo depois.

Dois rapazes com postura de poucos amigos atendiam à porta. Um deles perguntou a Newman o que este queria e reclamou de ter de dar troco, olhou para mim e perguntou se queria algo, ao tomar conhecimento de meu papel de acompanhante me mandou 'fazer o peão', ou seja, sair de lá, dar uma volta. Obedeci imediatamente, percebi que para estar com usuários de crack, assim como em qualquer outro contexto, há de se ter um papel a desempenhar. Ao caminhar em frente à 'biqueira', alguns menores questionavam minhas intenções, tive de usar a história do

33 Trata-se do vendedor de drogas. Alguém "no fluxo". Neste caso, ele se encontra fora do espaço seguro da "biqueira", ele estende o alcance desta até o meio dos usuários. 
'peão' para justificar minha presença por lá - 'Estou fazendo o peão', informei, e por isto, insisto, não se fica em um ambiente de compra ou uso sem uma justificativa, uma identidade, um papel. Newman sempre me apresenta, conta uma história, afirma ser eu tão louco quanto eles $e$ apenas observa o fato de seu acompanhante 'ter parado', antes de poder me colocar definitivamente como antropólogo. Neste sentido, somos sinceros.

Tomei distância de Newman além do necessário, por curiosidade, para ver os arredores. Depois disso, Newman vem ao meu encontro, retornamos à esquina passando pelo nosso carro e atravessamos a rua, imediatamente somos abordados pelo 'contenção'. Não se parecia com o congênere da 'biqueira' dentro da favela, mas com um usuário mais interessado em saber quem chegava para ser favorecido, do que alguém responsável pela vigilância do local. Com o tempo de campo, percebi a intrincada rede de prestações de serviços entre 'vapor(es)' e outros usuários. Ele mesmo brincou ao me ser apresentado por Newman como contenção, dizendo que faziam 'a contenção para eles mesmos', como se contasse apenas consigo para proteção própria. Newman se dirige a um barraco, um conjunto de plásticos pretos e um colchão de ar descosturado e aberto, cuidadosamente amarrados um ao outro, que vão da sarjeta até um muro e ao lado de um bueiro destampado, coberto por papelóes e plástico. O barraco de Zezé, um artista plástico carioca, conta com dois avanços laterais que não chegam a formar uma porta, mas auxiliam um pouco a isolar seu interior. Ao menos um pedaço de cobertor soma-se às lonas do teto e outros cobertores cobrem o chão próximo à parede em um criativo emaranhado que pode ser facilmente montado e desmontado como um sofá-cama. Ele proporciona um uso múltiplo e facilita a busca por objetos caídos, inclusive pedaços de pedra. A ligação com o muro é totalmente vedada até o chão. No final da calçada e após a guia, na sarjeta, o encontro da lona com o chão é sustentado por um carrinho de feira (disponivel para 'treta') e próximo ao carrinho forma-se um segundo ambiente com um colchão que faz às vezes de cama e outras cobertas, onde se pode igualmente sentar-se. Apoiado sobre o chão e encostado ao carrinho reside um espelho que reflete a luz da vela que ilumina tudo, ou quase. Todo conjunto repousa sobre placas de Madeirit e é muito confortável. 
Sentamo-nos e finda as apresentações o fluxo da pedra começa. Sou apresentado como 'loco que parou de usar', 'ex-viciado em farinha', 'aposentado', 'que conheceu a Muniz quando ainda era o portão', numa referência à 'biqueira' mais tradicional do bairro para quem calculamos ter três décadas, ao menos, de serviços ininterruptos prestados aos usuários da região central e centro-sul da cidade.

O trecho do caderno de campo que acabamos de reproduzir leva-nos a pensar sobre o início de nosso contato com o uso do crack, antes de nossa maior aproximação com este uso. Percebemos a continua e segura dissolução das noções preconcebidas até sua inversão rumo a uma maior identificação e reconhecimento dos valores morais, estéticos, dos gostos e preocupações, enfim, dos sentimentos próprios deste estilo de vida, desta parte de nossa cultura popular, a cultura do usuário de crack.

Em "biqueira" com fumódromo fica usuário e "vapor". Ir apenas observar e estar com eles é uma intromissão, causa desconforto, insegurança quando não franca hostilidade. Portanto, como fez Malinowski (1978, p. 22), cada vez mais: “Tive de aprender a comportar-me como eles e desenvolvi certa percepção para aquilo que eles consideravam como 'boas' ou 'más' maneiras."

Vimos nos parágrafos anteriores as dificuldades e artimanhas para acessar os usuários de crack. Fica patente a relevância de Newman (nosso interlocutor) como facilitador no acesso e socialização na "biqueira". Também nos começa a aparecer com maior clareza a importância ética de manter a revelação de nosso papel de pesquisador sob a responsabilidade do interlocutor, do nativo, afinal, trata-se de sua segurança no campo durante e após o término de nossa pesquisa. Qualquer atitude irresponsável e voluntarista por parte do pesquisador participante poderia colocar as amizades, reputação e mesmo a vida de nosso interlocutor e guia na introdução ao campo em risco. Contudo, em todas as situações de pesquisa, o papel de pes- 
quisador sempre pôde ser revelado em seu devido tempo. Mesmo com todas as precauções de Newman, nessa mesma noite, uma frequentadora do barraco de Zezé iria incomodar-se com o fato de lá me encontrar sem fazer uso do crack como todos os outros frequentadores do local. Isto geraria uma reclamação ao "contenção", a quem fora apresentado na chegada da "biqueira" e ele viria me ameaçar com uma faca dentro do barraco de Zezé.

\section{Quem é mais ladrão?}

Nos parágrafos seguintes, oriundos dos cadernos de campo de maio de 2013, somos levados a entrar em contato com outras atividades ilegais, além do tráfico e porte de drogas e nos deparamos com os dilemas éticos daí resultantes.

Após um mês da primeira visita à 'biqueira' da rua São Paulo, volto procurando por Zezé, responsável por instigante conversa em minha última visita ao campo. Desta vez vou só e encontro Newman no interior do beco ao lado de um carro de reciclagem puxado à mão. O encontro sentado no chão a preparar um 'boris', nome dado ao cachimbo de fumar crack, e logo me apresento a ele e ao 'contenção' que imediatamente surge para interrogar minhas intenções no local. Mostro alguns cachimbos que trouxera de recente viagem aos Estados Unidos. Estes, logo atraem a atenção e cobiça do 'contenção' e de outro usuário que estava ao lado de Newman. Vou explicando o funcionamento dos cachimbos, particularmente de uma caneta que esconde um tubo de vidro disfarçado. Em dado momento, o 'contenção' faz um movimento de pegar um cachimbo para si, mesmo sendo advertido por mim que este seria presenteado a Zezé. O cachimbo é rapidamente retirado de sua mão por Newman e, em seguida, o outro usuário a acompanhar a demonstração das novidades nos alerta do fato de Zezé haver entrado em desavenças com Russa, casada com o 'vapor' da 'biqueira', que aqui será chamado de Dobem. Ela é uma espécie de coordenadora deste e demais 'vapores' atuantes no local. Fico com a impressão de o presente para Zezé ter ficado sem dono, pois pode ser apropriado 
por qualquer um, contudo, isso não ocorre em virtude da intervenção de Newman. No local em que se localizava o barraco de Zezé havia outro de muito menor cuidado. Discuto isto com Russa logo após conhecê-la. Como observado, Russa é uma espécie de coordenadora dos 'vapores' do beco. Posteriormente, em outra visita a esta 'biqueira', viria saber por Cláudia, outra usuária de quem falaremos a seguir, do relacionamento de Russa com Dobem, como dito, um 'vapor' desta 'biqueira', relacionamento este não assumido em público. Havia ficado com esta impressão ao conhecê-la e observar o comportamento de ambos, porém, ao questionar Newman sobre a situação dos dois, este me garantiu que Dobem era 'bicho solto' (Para Cláudia, não haveria porque esconder o relacionamento entre os dois, para ela, 'a partir do momento que estão juntos é marido'). Pelo menos esta é a conclusão a que chego ao discutir seu status com Newman. Ela mesma, Russa, lamenta a falta de Zezé para manter o barraco em bom estado de conservação, mas observa que este foi expulso do beco por ter sumido com quarenta reais em moedas que ela lhe entregara para serem trocadas por cédulas. No fim das contas, o presente trazido para Zezé é dado por Newman à Russa. Aparentemente, esta como credora, acabou por fazer jus ao bem trazido para Zezé.

Dobem, o 'vapor' da 'biqueira', pede-me para levá-lo à Praça da Sé, na região central da cidade de São Paulo, distante pouco mais de uma estação de metrô do local da 'biqueira'. Ele me exibe um telefone celular. A 'treta', ou troca de coisas e dinheiro é o modo usual, além do empréstimo, de conseguir outras coisas, como as necessárias para fumar: isqueiro, cinza, cachimbo, cigarro, raspador e, principalmente, pedras de crack. Em visita anterior ao campo, chegamos a adquirir dois telefones celulares de Dobem para logo depois revendê-los dentro da 'biqueira', com algum prejuízo. A decisão de comprar partiu de $\mathrm{Ne}$ wman e a venda foi realizada por Zezé, de modo atribulado, sob pressão minha para abandonar o campo, dado meu cansaço pelo adiantado da hora. Não foi de imediato minha tomada de consciência da origem daquele bem nas mãos de Dobem, ele poderia ser fruto de 'treta', mas não, havia sido roubado pelo próprio Dobem. Em outras visitas percebi o motivo dos pedidos insistentes para levá-lo à região da Avenida Paulista. Era lá, numa região de escritórios, o lugar da realização dos roubos, mas aonde nunca cheguei a acompanhá-lo. 
Ao entrar em meu carro, Dobem começa a comentar seu desejo de comprar um veículo de chassis raspado e adulterado nos dois últimos números. Pergunto sobre como ficaria a documentação do veículo e ele responde algo sobre a origem ser de leilão. Dobem comenta sobre nossa última volta de carro em que fomos buscar dinheiro para pagar o 'bloco' consumido por Newman, de como a 'biqueira' havia ficado 'abandonada' e dele ter sido chamado a atenção. Dobem me pergunta se também roubo e explico ser professor, no máximo sonegador de fontes de rendimento no imposto de renda nos antigos tempos de viabilidade deste artificio. Aponto a ele minha 'cara de otário'. Chego a deixá-lo consternado: 'Ah, não fala assim. Você não tem cara de otário'.

Passamos ao lado da Praça da Sé e observo uma concentração, aparentemente, de usuários de crack e Dobem faz um comentário depreciativo sobre aqueles que lá se reúnem. Mais tarde, ao levar Newman para casa, este afirma estarem na Cracolândia os piores usuários, os sem condições de frequentar uma 'biqueira' melhor como a de Dobem. Na Praça da Sé ficariam os de condições não tão ruins quanto ao seu comportamento, em comparação com os da Cracolândia, mas também estariam em piores condições de conduta, em relação aos da 'biqueira' de Dobem. Ele faz a venda e retorna a nosso veículo vangloriando-se da quantia levantada, um pouco mais de cem reais a vista $e$ o restante a receber em alguns dias, totalizando, segundo ele, algo em torno de quatrocentos reais.

No caminho de volta à 'biqueira', Dobem simula apontar uma arma e disparar o gatilho na direção de uma senhora sentada no banco do passageiro de um veículo que parara ao lado do nosso em um farol. Ao nos aproximarmos da 'biqueira', Dobem pede para que se dê um 'cavalo de pau' em frente ao beco para marcar nossa chegada. Em dado momento, ao nos depararmos com uma contramão e minha negativa em prosseguir por este caminho, Dobem questiona se sou 'Vida Loka'. Termo usado para referir-se àqueles que se dedicam a um estilo de vida criminoso e também nome de um grupo musical da periferia da cidade. Faz questão de sair do carro ainda em movimento. Pode ser apenas um gosto pela emoção, mas parece mais a vivência de certo estilo de vida, 'sou da marginália, sou do crack', como um dia, e veremos a seguir, observou o próprio Dobem. Alego em minha recusa não ser mais adolescente para fazer tais coisas. Russa, esposa de Dobem, 
Jamais fomos zumbis

havia permanecido no local, para garantir o suprimento dos usuários e o funcionamento da 'biqueira'. Apresentar-se como 'Vida Loka' aos frequentadores da 'biqueira' quando possivel, aparentemente tem importância, paradoxalmente, a quem 'está na responsa', como Dobem.

Sobre o trabalho de campo observou Turnbull (1986) que ele nos propicia oportunidade para rever nossas próprias ideias e valores, nosso próprio ser. Durante este modo de pesquisa voltamo-nos para nós mesmos e abandonamos o antigo, estreito e limitado do self, para enfim descobrirmos um novo self apropriado ao novo contexto. Os antropólogos não dispõem de orientações suficientes no momento de fazerem suas opções éticas em pesquisas com interlocutores cujas atividades incluem atos de violência. (MACRAE; VIDAL, 2006) Procedimentos como a assinatura de atestados de consentimento se tornam surreais com pessoas procuradas pela polícia, por exemplo. Como a própria inserção no campo é negociada, os diálogos posteriores seriam consentidos por definição. (OLIVEIRA, 2004) Não faz sentido o consentimento para a autoincriminação de Dobem. Enfim, esta papelada para proteção aos seres humanos tem por objetivo mais a salvaguarda das instituições de pesquisa e menos os sujeitos pesquisados, em seus interesses e dignidade. (BOURGOIS; SCHONBERG, 2009)

Contribuir para a venda de produto roubado, certamente é crime e possui suas implicações legais e éticas, possivelmente não teria levado meu interlocutor ao local da venda de seu produto roubado caso tivesse todas as informações, primeiro de tratar-se de produto fruto de roubo e segundo de estarmos nos dirigindo à Praça da Sé, para lá, efetuar sua venda. A princípio estariamos apenas "dando um cavalo", ou seja, uma carona. Contudo, sem acompanhar os nativos, como cumprir o imperativo do ofício de antropólogo nos legado por Malinowski? 
Por outro lado, neste tipo de pesquisa, recomenda-se ao etnógrafo que de vez em quando deixe de lado máquina fotográfica, lápis e caderno e participe pessoalmente do que está acontecendo. Ele pode tomar parte nos jogos dos nativos, acompanhá-los em suas visitas e passeios, ou sentar-se com eles, ouvindo e participando das conversas [...] Esses mergulhos na vida nativa - que pratiquei frequentemente não apenas por amor a minha profissão, mas também porque precisava, como homem da companhia de seres humanos [...]. (MALINOWSKI, 1978, p. 31)

A companhia dos usuários de crack seguiu sendo, em todo período de trabalho de campo, a mais prazerosa e instigadora das interlocuções. Necessito estar com eles para a pesquisa de campo e desejo estar em sua presença pela oportunidade de discutir o tema de minha paixão intelectual atual - o uso coletivo na roda de crack. Com nenhum outro grupo, mesmo os acadêmicos, esta questão pôde ser tão bem compreendida, vivida e compartilhada. Sentarmos em sua companhia no cotidiano de suas atividades não nos pareceu coisa diferente de fumar com eles. Em uma roda de crack, fuma-se. Ou se faz um "corre", ou um "peão", se está ou não se está junto na "caminhada". ${ }^{34}$

No entanto, devemos tomar certo cuidado. Por tratar-se de ambiente relativamente próximo ao do pesquisador; por este possuir histórico de uso intensivo de drogas, o que poderia contribuir para obtenção da confiança necessária ao trabalho etnográfico baseado na qualidade das relações. Há sempre de se tomar precações para que a natureza da confiança e envolvimento pessoal nas relações de campo em excesso não enviese a pesquisa. (JOHNSON, 1983)

Para um debate sobre a oposição entre "experimentar lá" e "escrever aqui", outra questão se coloca: a de pensar a relação

34 "Corre", "peão" e "caminhada" são termos nativos fundamentais para se iniciar o trânsito na cultura do crack. São três dimensões do movimento. 
entre pesquisador e seus interlocutores como dispositivo central de construção do saber antropológico. Juntos, na "caminhada", nos tornamos "parças", e esta relação pode ter papel fundamental na construção do tipo de conhecimento antropológico que nos interessa. (ENGLUND; LEACH, 2000) Daquele que toma as atitudes de observador e observado como análogas, ou "reversas". (WAGNER, 1981) Pois afinal, o estudo da cultura, cultura é. Como na improvisação do jazz, todo ser humano inventa cultura. O ofício antropológico propõe a criação de uma narrativa a respeito do outro, que parte das relações construídas no campo. Quando se adentra na intimidade cultural nativa (HERZFELD, 1997), certos relacionamentos passam a ser constantemente negociados. O tipo e profundidade das informações que daí irá surgir dependem e mesmo provém, grandemente, da qualidade destas relações. Antes de se obter informações a respeito das relações entre nossos interlocutores, devemos construir relações com eles. (STRATHERN, 1999) É um movimento que vai das relações com eles para o saber sobre as relações entre eles.

Para a construção desse saber, ou para a produção de um discurso que se pretende simétrico (LATOUR, 1994), que não se coloque como superior ao discurso nativo. Quanto mais intensamente afetados formos pelas relações proporcionadas pelo campo e, principalmente, pelas mesmas forças que atuam sobre eles, naquilo que para nós é o campo e que para eles é a vida. Isto permite ao etnógrafo sentir, não a sensação no outro, mas em si, as consequências de estar na mesma posição do interlocutor. (FAVRET-SAADA, 2005) A partir deste encontro, a escrita etnográfica pode se dar do modo mais profícuo. Quando aceitamos participar ativamente da roda de crack, era atrás disto que estávamos. Não significa assumir o ponto de vista do usuário de crack, ou buscar algo oculto por trás de suas práticas, mas construir um ponto de vista a partir do ponto de 
vista da nossa relação com o ponto de vista nativo. (VIVEIROS DE CASTRO, 2002)

Malinowski (1978) fornecia tabaco aos trobriandeses em troca de permissão deles às investidas do pesquisador sobre os assuntos tribais, assim como a fim de estar em posição de fazer boas questões e obter boas respostas. Gerald Berreman (1962), em sua pesquisa no norte da Índia, valeu-se dos serviços de um intérprete abstêmio de álcool e não comedor de carne, três meses se passaram e seu intérprete adoeceu sendo substituído por um muçulmano bebedor de álcool e comedor de carne. Apenas então, Berreman pôde saber do costume de se realizarem festas intercastas com bebidas alcoólicas e carne. O acesso a informações dos mais variados tipos só foi aberto após os moradores saberem da ocorrência de ocasiões de uso da bebida alcoólica local na casa de Berreman.

Os limites da atuação do antropólogo em campo foram colocados em questão na descrição acima. "Dar um cavalo"35 ao Dobem, ele passou posteriormente e de modo insistente a me pedir para guiar o carro e tive de encontrar formas de recusar sem ofendê-lo, da mesma forma como me neguei a dirigir pela contramão e guiar do modo espetacular desejado por ele.

\section{Os interlocutores Cláudia e Salomão no morrinho}

Como nos vestimos de maneira diferenciada do comum dos frequentadores da "biqueira", mas principalmente através de Newman foi possivel adquirir muitas pedras, isto deu uma forte impressão de que a nossa presença causava algum desequilíbrio no campo e em três oportunidades, este fato pareceu bem claro. Na primeira delas, Dobem estava "na responsa", trabalhando, vendia certa quantidade de pedras e retornava à "biqueira" para buscar outro montante; este era novamente vendido. Sua respiração ofegante parecia haver se tornado

35 "Dar um cavalo" significa transportar alguém para algum lugar. 
parte de sua identidade, acompanhada pela tosse constante. Ofegante pela correria que compreendia, na prática, a travessia de dez pistas em avenida movimentada - ligações das regiões leste e oeste da cidade. Dobem vendia enquanto usava e vice-versa. Pelo nosso lado do barraco, ele adentrou certa feita com uma sacola branca contendo duas caixas de celular fechadas. O negócio foi rapidamente realizado para certo espanto geral, inclusive meu que teria de desembolsar "emprestado" o dinheiro para Newman. Quando saímos a campo, sabemos que é sobre o antropólogo que recaem parte dos gastos. Em meio a breve negociação, Zezé protestou que não queria "treta" em seu barraco, pois Dobem havia realizado a venda para Newman e entrara de modo intempestivo, ofegante, arfando e transmitindo um senso de urgência no conjunto de suas atitudes. Newman havia também adquirido dois "blocos". O protesto de Zezé gerou um conflito e fomos convidados por Dobem a dirigir-nos a outro barraco que providenciara logo após a discussão com Zezé. Dobem chegou a desdenhar de Zezé publicamente declarando não ser ele sequer malandro. Soubemos, mais tarde, da animosidade antiga entre os dois. Cerca de um mês depois, Zezé deixa a "biqueira" ao furtar $R \$ 40,00$ pertencentes a Russa.

A segunda oportunidade de desavença causada no campo, talvez devido a nossa presença, aconteceu enquanto esperávamos, sem a companhia de Newman (já nos dirigindo à "biqueira" sozinhos), a volta de um usuário chamado Salomão de outra "biqueira" próxima, a "29", com os "blocos" encomendados para ele. Neste momento, o "contenção", aparentemente por nos ver na companhia de Cláudia, usuária amiga de $\mathrm{Ne}$ wman, imagina o "fluxo" acontecendo. Ela procura explicar as circunstâncias, porém, o "contenção" recusa-se a ouvi-la e surge uma discussão ríspida entre ambos até a chegada breve de Salomão. Cláudia foi acusada de estar mentindo e de tentar esconder crack. 
Cláudia para Ygor - Eu falei pra você por um 'trago' aqui? Ygor - Nããão. É que ela tá me explicando como é que faz pra puxar.

'Contenção' para Ygor - Não brother, você não tem nada a ver, não. Você aqui é turista.

A terceira ocorrência foi no momento de "dar um cavalo" para Dobem até outra "biqueira da mesma firma", de onde vêm as pedras comercializadas no local da pesquisa. Ao nos ver deixando o local com Dobem, Cláudia bate no vidro do carro e me convida a juntar-me a ela quando de meu retorno. É repelida por Dobem; ela retruca dando a volta no veículo e batendo fortemente na janela ao lado dele de modo ameaçador. Em ocasião anterior, a ser descrita em seguida, o usuário Salomão preocupa-se em levar-me sem muita demora de volta à "biqueira", tendo em mente um compromisso firmado por mim com Dobem, de conduzi-lo à região da Avenida Paulista. Compromisso acertado em frente a Salomão, mas não cumprido posteriormente.

Em nossa primeira incursão à "biqueira" a céu aberto sem a companhia de Newman somos recebidos por Salomão, ele fazia a "contenção" no momento, mas poderíamos considerar também sua estada ali de modo oportunista, aguardando a chegada de alguém com quem pudesse fumar. Em outra visita, a pessoa disposta na mesma esquina limitou-se a encaminhar-me ao local onde deveria, teoricamente, realizar a compra dos "blocos".

Certamente, envolver-se nas trocas levanta um problema ético. A troca, como elemento fundamental de inclusão e exclusão de indivíduos na comunidade de usuários de drogas foi amplamente debatida em pesquisa com consumidores de heroína nos Estados Unidos. Os antropólogos detectaram que a comunidade de usuários se mantinha através de uma economia moral das trocas (BOURGOIS; SCHONBERG, 2009), esta economia os envolve em uma rede de relações mútuas e definem os limites da comunidade. Ou seja, faz parte quem troca. Não 
trocar é ser antissocial e arriscar-se a ser levado ao ostracismo. Os autores preocuparam-se em não comprar informações, ou tornarem-se patrões, mas não poderiam ficar alheios à forma corriqueira (troca de alimentos, dinheiro e drogas) de definir e expressar amizade, organizar hierarquias e excluir outsiders indesejáveis. Tiveram de aprender quando dar e quando negar, e concluem com a importante observação da inadequação das regras mais dogmáticas de pesquisa à realidade das ruas.

Roberto Cardoso de Oliveira (2004) ao criticar a Resolução n. ${ }^{\circ}$ 19/96 da Comissão de Ética em Pesquisa do Ministério da Saúde para regular os aspectos éticos das pesquisas com seres humanos discorda da extensão das preocupações com as pesquisas biomédicas para a antropologia, isso teria ignorado a realização por parte desta última, de pesquisas com observação participante entre populações ocultas, além de ignorar a diferença entre pesquisas em seres humanos (caso da área biomédica) e com seres humanos (situação da antropologia social e cultural). O paradigma da primeira é a relação com cobaias, da segunda, com interlocutores, neste caso, marcado pela negociação nos mais variados aspectos das interações ocasionadas pela incursão do antropólogo no campo, onde até o próprio objeto da pesquisa será negociado.

$\mathrm{Na}$ antropologia, os sujeitos da pesquisa são antes concebidos como pessoas, entidades socioculturais e a questão ética posta nesta relação de alteridade marcada pela diferença é o respeito por seus costumes, comportamentos e práticas. (CAROSO, 2004) É inevitável ao pesquisador de comportamento desviante, sujeito a sanções na forma da lei, infringir certas leis. (BECKER, 2008) Sabemos ser da Lei n. ${ }^{\circ} 11.343 / 06$ a penalização para quem "induzir, instigar ou auxiliar alguém ao uso indevido de drogas", em seu Artigo 33, parágrafo 2. Ficaria assim vedada, uma postura tolerante nas pesquisas com usuários de drogas em relação às suas práticas. Prossegue-se com 
as anotações do caderno de campo de setembro de 2013 sobre o ocorrido com Salomão e Cláudia.

Após a chegada de Salomão com as pedras, dirigimo-nos ao
outro lado da rua, até o barraco de Cláudia. Sentamo-nos
e outros usuários tentaram se aproximar e foram sendo
desencorajados pelo casal. Salomáo havia me passado
os blocos e os repasso à Cláudia. Logo percebem minha
inexperiência e falta de habilidade no uso do crack. Esta-
mos sob lonas e cobertores, acomodados sob um barraco
com um metro de altura no máximo. Salomão ressalta o
impacto agressivo do uso sobre os pedestres e do respeito
que, no meio dos usuários, propugna-se ter com as crian-
ças que, por ventura, possam valer-se daquele local como
passagem. Minha falta de habilidade, meu rosto gordo e
as vestimentas logo levam a suposições sobre meus pro-
pósitos reais. Salomão - Você é bem comedido. Você não fuma crack constantemente, né?

Ygor - Não, muito raramente.

Salomão - Esporádico, né?

Ygor - Esporádico. Sou um usuário recreativo. (Risos).

Salomão - Acho que você usa pra ter uma penetração nos lugares, assim também. Pra poder não ficar muito deslocado.

Ygor - Pra poder trocar ideia.

Salomão - Pra poder trocar ideia.

Logo sou convidado a seguir para outro lugar de uso mais isolado conhecido como Morrinho, trata-se do canteiro lateral da Avenida Radial Leste, a principal ligação da Zona Leste da cidade com as zonas Oeste e Sul. ${ }^{36}$ Para chegar ao ingreme local é preciso pendurar-se em uma grade de isolamento entre um viaduto e a Praça Almeida Júnior. Fica-se pendurado sobre a Avenida Radial Leste com suas dez pistas e carros em velocidade. A ida em relação ao retorno foi mais fácil, o uso do crack não melhora minhas habilidades motoras. O local é também propício ao encon-

36 Os "righteous dopefiends" estudados por Phillippe Bourgois e Jeff Schonberg usavam as laterais e baixos de viadutos das freeways californianas para utilizar heroína, álcool e outras drogas. (BOURGOIS; SCHONBERG, 2009) 
tro amoroso e sou alertado do fato pelo casal a me acompanhar.

Salomão - Isso aqui é um terreno acidentado [...] bastante pedra. A gente gosta de fumar ali, tem uma grade aqui no viaduto, tem o Morrinho. A gente gosta de ficar muito ali, tranquilo. Onde os caras levam as menininhas pra ficar de boa. Uma manta.

Cláudia - Uma companhia pra [...] (risos).

No caminho do Morrinho encontro um "vapor" da "biqueira", Dobem, e este me solicita uma carona à Avenida Paulista. Em uma próxima visita ao campo, ele faz o mesmo pedido e revela sua intenção de ir a esta importante via de São Paulo para realizar roubos. Por fim, acabei não o conduzindo a tal avenida. Como relatado, eu o havia levado, inadvertidamente, à Praça de Sé para efetuar a venda de um aparelho celular. Uma forma utilizada neste campo para tentar maior aproximação e quebra de desconfianças foi a alusão ao meu passado como usuário pesado de drogas. Repetimos, não sei se com sucesso, a mesma tática no Morrinho, o que pode ser visto nas anotações extraídas do caderno de campo de setembro de 2013.

\begin{abstract}
Após consumirmos a primeira pedra, Salomão faz menção ao desejo de ausentar-se para deixar eu e Cláudia a sós naquele local de encontros amorosos dos usuários da biqueira. $^{37}$

Salomão - Ó, eu vou me ausentar, pra deixar vocês aí.

Claudia - Por quê?

Ygor - Não. Fica aí, vamos fumar mais uma pedra aí.
\end{abstract}

37 Em uma próxima visita ao campo, ao dar uma carona ao "vapor", este me indaga se tenho interesse em namorar alguém na "biqueira". Apesar de minhas observações sobre meu estado civil de casado, Dobem insiste perguntando detalhes de meu gosto feminino e descrevendo algumas usuárias, em busca de conhecer minhas preferências no assunto. Ao ver minha insistência em negar algo possivelmente correspondente a um comportamento esperado no local - ter uma namorada - passa a desconfiar de minha sexualidade e a perguntar se realmente possuo interesse em mulheres. 
Claudia e Salomão permanecem divertindo-se em me instruir no uso. Fazem observações sobre a duração e intensidade dos efeitos, assim como da 'fissura'. Salomão diz: 'A brisa boa é quando dá um tuim'. Comentam de sua inadaptação a outras drogas e das possibilidades de se incrementar os efeitos do crack pelo uso da rapa. ${ }^{38}$ Espantam-se por eu nunca haver usado meu cachimbo e fazem questão de experimentá-lo. Salomão fala da importância da 'circunstância', da necessária sintonia entre os usuários para obter-se o efeito desejado do 'trago', ou brisa. É necessário 'pegar bem' com as pessoas na roda de crack. 'Porque a pedra, ela só [...] ela abre caminho' diz Salomão. Em sintonia com ambos foi, creio eu, meu estado naquele momento. Dai surgiu um imperativo ético. Neste momento, explico aos dois minha posição de pesquisador no campo. Salomão é soteropolitano e falamos um pouco sobre sua cidade. Ele me conta a respeito de outros pesquisadores que apareceram na biqueira com o intuito de filmar o local. Ele revela que pensava realmente que eu fosse jornalista, ou policial. Revelo minha preocupação em não ser visto desta maneira e ele me recomenda utilizar um boné. Posteriormente, quando chegarmos a combinar dele me acompanhar a outras biqueiras, ele irá recomendar-me que use roupas mais velhas para não chamar a atenção policial. ${ }^{39}$

A partir do texto retirado do caderno de campo e transcrito acima, vale a pena tecermos algumas considerações. Após alguns anos de pesquisa de campo, o sociólogo William Foote Whyte escreveu Sociedade de Esquina e nesta obra, descreve e analisa a organização social e a cultura dos jovens italo-americanos de um bairro apelidado por ele de Cornerville, no Boston's North End. Residiu e participou ativamente da vida social e política da comunidade italiana daquele bairro, chegando a fazer parte de clubes e sendo eleito para ocupar cargos de certa importância. Para ele, apenas dar uma volta com os rapazes de Cornerville não

38 "Rapa" é o nome dado ao produto da sublimação da fumaça oriunda da queima da pedra de crack depositado dentro do cachimbo.

39 Alguém burguesamente trajado acompanhado de usuário em seus trajes mais condizentes com a situação de rua, poderia atrair o zelo policial pela classe média. 
era suficiente para fazer uma pesquisa sobre a sociedade de esquina. Era necessário saber quais perguntas deveriam ser feitas e quando poderiam acontecer (WHYTE, 2005), mas em todo caso, se fazia necessário dar uma volta. Foi o que fizemos.

Sobre a "sintonia", ela é algo fundamental no uso do crack. Para poder usufruir os efeitos esperados não basta dar um "trago". Entre os usuários deve haver uma boa relação, uma espécie de harmonia nas atitudes, mas a "sintonia" é, certamente, também efeito da droga. A pedra só abre o "caminho", percorrê-lo na companhia de um "parça", com o casal, ou mesmo com um desconhecido recém-chegado à "biqueira" é uma possibilidade aberta pelo uso. Estarem todos em "sintonia" é um prazer em si mesmo e porque não o principal prazer possibilitado pela pedra e pelo ambiente? A satisfação proporcionada pela disposição de pessoas em roda, compartilhando uma mesma atividade e fumaça, dialogando, não é exatamente uma novidade nas possibilidades abertas pela vida social. Tudo maximizado por uma substância alteradora de humor, seu uso une e agrega, torna a presença do outro desejável para perfeita fruição das possibilidades abertas pelo crack, abridor de caminhos. Neste sentido, a "sintonia" é a "brisa".

A revelação do nosso papel naquela efêmera roda de crack formada por nós três no canteiro lateral da mais importante e movimentada ligação entre as regiões leste, sul e oeste da cidade, foi um efeito da "sintonia" do grupo e tornou possivel o desvendamento de minha condição de pesquisador, desde pouco antes intuída por Salomão. Assim como esta mesma "sintonia" tornou insuportável para mim a manutenção de qualquer segredo, ou disfarce. Para Galliher (1983) mesmo ao assumir a condição de nativo durante a pesquisa de campo, deixar clara nosso papel de pesquisador evitaria prática semelhante à espionagem. Vimos acima, como o imperativo da interlocução vem do campo, ele abre a possibilidade da clareza de intenções. Esta não é a priori, infelizmente há riscos não apenas para a 
maior ou menor probabilidade de se obter bons dados etnográficos, mas à própria integridade física do investigador e também dos interlocutores, como no caso de Newman.

A realização de um trabalho etnográfico significa a escolha por opções de comportamento e cumplicidade no campo (VAN MAANEN, 1983), escolha do que será ou não publicado, não havendo como não desagradar alguém por tratarem-se sempre de opções a serem feitas entre alternativas que agradam uns em detrimento de outros. Nossa escolha pela participação em práticas tornadas ilegais pela legislação proibicionista foi, em parte, facilitada por um histórico pessoal de vivência das mesmas práticas. Tanto quanto a escrita foi fortemente influenciada pelas escolhas feitas durante o trabalho etnográfico, isto também ocorreu na análise dos dados. Ao saber da pesquisa, Salomão e Dobem mostraram-se interessados em seu conteúdo. ${ }^{40}$ Há uma preocupação dos interlocutores com o conteúdo do trabalho, com a dimensão da amostra e sua significância.

Salomão - Mas você pode correr outros pontos, não pode? Ygor - Posso.

Salomão - Ó, tem a Barão.

Ygor - Se você puder me levar um dia?

Salomão - Ó, tem a Barão, pra cá tem o Gramado que também é uma 'biqueira' legal.

Claudia - 'biqueira tour'.

Ygor - 'biqueira tour', exatamente.

Salomão - Pra você conhecer, pegar outros tipos de depoimento.

40 Dobem, curioso sobre minhas intenções com o cachimbo - Esse aí vai observar né? Os alunos.

Ygor - Como é que é?

Dobem - Vai mostrar né? Você tá fazendo pesquisa.

Ygor - É, vou mostrar. Vou mostrar esse dele, que esse aqui é bem loco.

Dobem - A rapa, você vai mostrar?

Ygor - Então, preciso aprender como é que tira.

Washington - A rapa desse aqui é boa.

Ygor - Desse cachimbo? 
Ler a respeito da experiência etnográfica não é passar por ela, não é dar um "trago"nas margens quase inacessiveis do viaduto. O mundo a se entrar como leitor deste trabalho, não é a experiência direta da vida nas esquinas da sociedade, estando o autor engajado na interpretação desta, como reconstrução, inscrita no texto, assim, o texto produzido não pode determinar como seus leitores irão interpretá-lo. (ATKINSON, 1990) Contudo, tomamos o cuidado para não produzir nos leitores um efeito inverso ao pretendido, isto é, esforçamo-nos por apresentar nossos interlocutores em toda sua dignidade, como pessoas interessantes, inteligentes e plenas no domínio de sua vontade. Pretendemos contrapor-nos ao discurso midiático de "culpabilização das vítimas" (MACRAE, 2013, p. 7), mas sabemos também que, infelizmente, ao tomar contato com os dados colhidos no campo, pela leitura de uma etnografia, o leitor está livre para interpretá-los do modo mais negativo possivel e terminar a leitura mais convencido de seus preconceitos e igualmente engajado na produção da morte social dos usuários.

Marcel Mauss (1974) formulou o conceito de morte social ao tratar da "sugestão coletiva da ideia de morte" entre povos australianos e malaio-polinésios. São mortes socialmente provocadas por magia ou pecado, ambas capazes de romper a profunda ligação do sujeito com as "coisas sagradas" e provocar neles a crença do fim iminente. "A consciência é então inteiramente apoderada por ideias e sentimentos que são inteiramente de origem coletiva [...]" (MAUSS, 1974, p. 190) e os pensamentos mórbidos de encantamento ou culpa levam ao óbito. Creem os australianos sobre a morte, que se estas não são violentas serão certamente de origem mágica. A magia geralmente faz cometer o pecado e este leva à ruptura da comunhão com as potências sagradas. $\mathrm{O}$ indivíduo tem chance de sarar mediante cerimônia de exorcismo, um contra feitiço ou espírito protetor. Todo este conjunto de crenças e práticas possui a mesma ori- 
gem coletiva. Para o autor, a força física destes povos contrasta com sua fragilidade frente à ideia do encantamento, do pecado e da magia. No caso polinésio, a moralidade seria a maior causa de mortes, principalmente por pecado mortal. Magia e pecado atuam um em função do outro, ora magia provocando o pecado, ora o pecado possibilitando a eficácia da primeira. A consciência de estar enfeitiçado pode provocar a morte rápida por prostração ou por melancolia. Aí, o social encontra o biológico, não por vontade ou escolha pessoal, sequer por ideação involuntária, mas pelo medo provocado pela sugestão coletiva desorganizar toda a vida. "O indivíduo encantado, ou em estado de pecado mortal, perde todo controle sobre sua vida, toda escolha, toda independência, toda a sua personalidade". (MAUSS, 1974, p. 207)

Os usuários de crack também passam, em certa medida, por um processo de morte social. A suposta perda de domínio sobre a vontade, justificativa para medidas agressivas como a internação involuntária, dá-se mais por efeito de certo conjunto de crenças a respeito do uso do crack e destas crenças sobre as ações dos não usuários e menos por qualquer propriedade farmacoquímica associada à droga. Como observou certa vez um usuário a dialogar comigo, ambos sentados no meio da rua, durante uma festa junina na Cracolândia: "E o pessoal, aî? Devem pensar que a gente é lixo [...] Eles passam pela gente como se fôssemos lixo."

Também a mídia se encarrega de caracterizá-los como zumbis, o morto vivo propriamente dito. (BOES, 2011) É como se houvessem cometido suicídio ao valerem-se da "droga que mata", mas permanecessem ainda meio vivos, moribundos, na espera da morte certa. São definidos e desqualificados pelo uso de certa substância sem dominar sua produção, preço, qualidade, quantidade e disponibilidade. Tamanha alienação é precariamente compensada pela emergência da cultura da droga e de uma vida comunitária. A perda da vontade é imposta de fora 
para dentro e não o inverso. Não é o usuário sob efeito do crack sem domínio de seus desejos e atos, mas sim, o "nóia" socialmente construído e subsumido a um mercado e uma legislação alheia à sua vontade.

O pecado cometido de abrir mão da vida, de "sustentar o tráfico", de "ter de roubar para sustentar o vício" abre espaço para a maldição, a sentença de morte: “[...] e seus amigos os contemplam sem escutá-los, sem nada fazer, aceitando sua sorte sem aflição". (NEWMAN, 1882, p. 471) O estudo de Newman (1882) foi citado por Mauss em seu trabalho sobre a morte social, porém, ele esconde um dado importante constante do texto original. ${ }^{41}$ Aí, Newman logo acima e no mesmo parágrafo citado, descreve as prováveis causas para a morbidez por depressão entre os Maori da Nova Zelândia. Ela está na perda de seus campos agriculturáveis, de seus cemitérios, dos rios e lagos para pesca; da consciência de seu decréscimo populacional na época da colonização. Isto nos suscita pensar na concretude material desta morte social. Ela é também a retirada dos meios de reprodução da vida, do emprego, da casa, da vizinhança e do bairro. O usuário da Cracolândia foi, muitas vezes, expulso não apenas da residência familiar, mas também do bairro, da "biqueira" próxima ao seu local de moradia, onde possivelmente muitos deles iniciaram sua carreira no crack. Como observou certa vez nosso informante-chave Newman: "quem está na Cracolândia é porque não consegue frequentar 'biqueira' decente”. Os usuários não perderam o domínio sobre a vontade, eles a usam diariamente em suas "correrias", porém, lhes foram negados os meios de satisfação de sua necessidade de obter e usar a droga de uma forma diferenciada da impingida pelos não usuários, ${ }^{42}$ pelo mercado desregulamentado (tráfico) a par-

41 Disponível durante o período de realização desta pesquisa para consulta na internet em: http://rsnz.natlib.govt.nz/volume/rsnz_14/rsnz_ 14_00_ 006550.pdf.

42 Pelo menos publicamente. 
tir do Estado. O usuário fiel ao seu estilo de vida não perdeu o controle sobre sua existência, sua capacidade de fazer escolhas e sua independência, ele nunca às teve como usuário. Foi-lhe sempre vedado possuí-las, seja pelo mercado ou tráfico, seja pelo Estado, enfim, por toda máfia antidrogas. (BUCHER; OLIVEIRA, 1994) A proibição abre as portas da condenação, assim passou com a maconha e a população escrava recém liberta no Brasil. (ALVES, 1998) O morto-vivo, o zumbi, o abjeto (RUI, 2012), qualquer segmento desta maneira caracterizado acaba candidato a ser alvo de políticas de higienização, ou puramente repressivas. ${ }^{43}$

Depois de esclarecida minha identidade como antropólogo, o programa de pós-graduação do qual era oriundo, nosso orientador e mais algumas considerações sobre lembranças comuns do bairro de Ondina em Salvador, as desconfianças diminuem ainda mais e Salomão sugere a necessidade de conhecermos outras "biqueiras" e fumódromos para dar maior abrangência à pesquisa. Também me aconselha a não fumar e conversar com Claudia sobre sua determinação em não aproveitar-se da situação a ponto de me induzir ao uso e tirar daí vantagens. Isto poderia nos permitir pensar na visão dos usuários sobre eles mesmos e seus pares, em como passam a internalizar a visão negativa construída, principalmente, pela mídia sobre eles. Como a existência na rua vai formando, com exemplos retira-

43 O fim de escravidão abre espaço para toda uma estratégia de normalização da sociedade e será posta em prática no Brasil, por médicos, higienistas e sanitaristas. Foi desencadeado um verdadeiro processo de medicalização da sociedade brasileira, como uma intervenção social intensa, autoritária e sem fronteiras. Segundo Roberto Machado, para estes profissionais médicos, os inimigos do corpo social eram os "excessos e desvios", para combatê-los fazia-se necessário disciplinar a sociedade, incutindo valores e deste modo destruir os "vícios e perversões" que ameaçavam os centros urbanos. A medicina, portanto, não se caracterizou somente pela "promulgação de leis ou por uma ação lacunar fragmentária, de repressão aos abusos, mas exigiu a criação de uma nova tecnologia de poder capaz de controlar os indivíduos e as populações, tornando-os produtivos ao mesmo tempo que inofensivos." (MACHADO, 1978, p. 156) 
dos de histórias repetidamente contadas e experiências vividas, uma imagem do usuário ardiloso, repleto de conhecimento sobre como sobreviver na rua, a partir, de algumas estratégias com certo nivel de trapaça. Ao demonstrar sermos ético e correto com Salomão, ele aparentemente sentiu-se obrigado a agir de modo recíproco comigo. Sua única recomendação foi sobre meus trajes. Deveriam ser mais modestos a fim de não chamar a atenção da polícia sobre nós, eles poderiam resolver me proteger de Salomão. Michael Agar (1980) em sua pesquisa com usuários de heroína nova-iorquinos foi energicamente compelido por eles a adaptar-se ao seu modo de vida para não colocá-los em risco. Para estar com meus interlocutores é preciso não comprometê-los com a polícia, dominar alguns códigos, certas posturas e não ser descuidado, ou "vacilar" em meio a uma atividade ilegal. Philippe Bourgois (2003) comenta suas dificuldades de homem branco em El Barrio, região de Nova Iorque e local de sua pesquisa. Como era frequentemente abordado pela polícia por suspeita de ser um usuário em busca de drogas, ou simplesmente um otário perdido em local inapropriado a alguém de seu status, Bourgois em sua pesquisa com usuários de heroína, teve nos constrangimentos legais, sua preocupação mais imediata. A simples presença dos pesquisadores foi cogitada por ele como algo possivelmente perigoso aos usuários.

Contei com as possibilidades abertas pela presença de Newman no início de minha investigação, somadas à disposição em frequentar os locais de uso, os territórios psicotrópicos sob a fumaça constante, no beco, este espaço ao mesmo tempo, ponto de mercado e ponto de uso. (FERNANDES; PINTO, 2004) Newman viabilizou a presença no campo com chances de acompanhar práticas, e certamente, discursos e racionalizações provenientes de meus interlocutores, de certa forma mais próximos à condição de "parceiros". Da tensão inerente ao trabalho etnográfico, entre mais observar ou mais partici- 
par, se pode concluir que nesta pesquisa, caso o meu papel de observador se destacasse em relação ao de participante, teríamos de dispor de muito mais tempo para conseguir atingir a condição de "parceiro". Na pesquisa etnográfica da antropóloga Luana Silva Bastos Malheiro (2013) em região do centro velho de Salvador/BA, valeu-se de sua condição de redutora de danos para aproximar-se dos usuários, porém, demandou um período de oito meses de contato até poder presenciar as cenas de uso. O trabalho de Bruno Ramos Gomes e Rubens Adorno sobre as trajetórias de usuários de crack no centro de São Paulo também se valeu da condição de profissional atuante em redução de danos do primeiro, como modo de acessar o campo. (GOMES; ADORNO, 2011) Em sua pesquisa sobre uso de crack entre prostitutas da região da Luz, no centro de São Paulo, Selma Lima da Silva valeu-se da companhia de membros da Pastoral da Mulher Marginalizada da Arquidiocese de São Paulo e precisou vencer a resistência destes à pesquisa. (SILVA, 2000) Caso extremo foi uma pesquisa de doutoramento em antropologia social com o trabalho de campo integralmente mediado por programas de redução de danos. (RUI, 2012) A pesquisadora passou sete meses em negociações com o programa para visitar locais de uso na cidade de Campinas, no estado de São Paulo e não estava autorizada a fazê-lo sozinha. Também lhe foi vedado o uso de gravador e "algumas perguntas jamais puderam ser feitas”. (RUI, 2012, p. 35) Ficou totalmente restrita aos horários, contatos e trajetos das equipes de redutores. Era-lhe até proibido levantar os históricos de uso de drogas e chegou a ser diversas vezes repreendida por seu comportamento como "redutora". Mesmo nestas condições, ir para o campo sozinha sequer foi cogitado pela futura doutora em antropologia, apesar de afirmar ter destreza para circular nestes espaços por sua experiência pregressa como "educadora de rua". Os usuários são por ela considerados uma "população de dificil acesso" e a pesquisa sem estas "instituições legitimadas" seria para ela 
"quase inviável". ${ }^{44}$ Desta perspectiva, a autora pretendeu estudar o consumo abusivo realizado, segundo ela, por uma pequena parcela dos usuários e reconhece ter conseguido dados de qualidade apenas "razoável". ${ }^{45}$

Um trabalho etnográfico sobre uso de drogas injetáveis na região central de São Paulo, com interlocutores de classe média e outros provenientes do lumpesinato foi levado à frente por Osvaldo Fernandez, entre o final dos anos 1980 e início da década de 1990 do século passado. O estudo contempla práticas "pesadas" entre usuários socialmente distantes do antropólogo, observados nas cenas de uso. ${ }^{46}$ Este se assemelha mais ao tipo de pesquisa de campo sobre drogas, desenvolvida aqui.

\section{0 uso do gravador e câmera fotográfica levanta a questão da segurança do pesquisador e interlocutores}

Observamos diversas vezes a disposição dos usuários de crack, frequentadores de um mesmo local de uso e convivência, em comentar sobre os acontecimentos locais. Contudo, após ter

44 O inverso pode ser dito dos redutores de danos com quem ela diz compartilhar experiência educacional e gostos por viagens e profissionais.

45 A autora decidiu pela pesquisa com o tema do abuso do crack e não sobre o trabalho das equipes de redutores, um contraponto à pesquisa anterior da antropóloga sobre comunidades terapêuticas, após perceber o apelo do tema do uso do crack. Ou nas palavras dela: "Mais uma vez, enfatizo que o tema central, o consumo de crack, acabou se impondo durante o trabalho: não só porque tive mais contato com usuários dessa substância devido ao acompanhamento das atividades dos programas de redução de danos, mas também e, sobretudo, porque durante a pesquisa o crack acabou ganhando notoriedade inesperada". (RUI, 2012, p. 45)

46 A outra rede de entrevistados poderia ser conceituada como lumpesinato: sem remuneração/moradia fixa, com baixo grau de escolaridade, composta de dois travestis, dois presos, um homossexual e um bissexual. Os travestis trabalham na prostituição de rua, sendo um deles paciente de Aids na casa de apoio Brenda Lee. Na segunda rede de usuários percebemos, quando comparado com a rede de classe média, um número maior de pessoas com problemas com a lei, prisões e com mais casos de HIV/ Aids. Nessa última rede também há um número maior de indivíduos que recorreram a tratamentos psiquiátricos e psicológicos". (FERNANDEZ, 1997, p. 104) 
revelado nosso papel de pesquisador a Claudia e Salomão, por exemplo, e feito observações sobre a necessidade de manter-se sigilo sobre estarmos realizando uma pesquisa de cunho antropológico, percebemos, em nossa visita posterior ao campo, a indiscrição de nossos interlocutores. Na incursão seguinte ao campo, Dobem, ao conversar conosco em seu barraco, na presença de sua companheira e coordenadora da "biqueira", a Russa, veio questionar-me se eu seria algum jornalista, como quem já houvera sido informado de algo. Pergunta se estaria gravando a conversa. Importante observar que nas visitas anteriores ao campo havíamos feito uso de celular para proceder às gravações, porém, o aparelho, se visivel, causava imediata agitação entre os usuários e imediatamente tínhamos de colocá-lo em local não visível. Este tipo de aparelho é moeda de troca na "biqueira". Também seria impossivel o uso de caderneta de campo, estas ferramentas para registrar dados incomodam, assim como perguntar demais também pode "roubar a brisa" de alguém, fazê-lo (a) "perder o trago". Assim, adquiri outro tipo de gravador, mais discreto, na esperança de causar menor impacto visual nos ambientes de uso. Um pen drive mostrou-se muito apropriado, usei-o sempre após consulta aos presentes, porém, possivelmente por suas dimensões reduzidas causava menor desconforto aos usuários de crack e logo era esquecido.

$\mathrm{O}$ certo é restringir sua utilização à concordância dos interlocutores e após o esclarecimento sobre nosso papel de pesquisador. Outro procedimento se assemelharia a espionagem, como afirmado acima.

Porém, nada neste campo é simples. Cheguei a presenciar fatos muito comprometedores à segurança, tanto minha, quanto de meus interlocutores. Como por exemplo, o "resumo da biqueira". Situação tensa de contagem do dinheiro e acerto de contas entre a Russa, os "vapores" e um responsável da "Estudantes", como eles chamavam a "biqueira" localizada na rua dos Estudantes (São Paulo/SP), a "biqueira" provedora dos 
Jamais fomos zumbis

"blocos" comercializados na "biqueira"com fumódromo por eu frequentada. Ao chegar para dar início a contagem das notas e realização das contas, o enviado da "Estudantes" me encarou de modo desconfiado por alguns segundos, com seu rosto a uma distância de um palmo aproximadamente do meu. Com a intervenção de Newman, ele se acalmou.

\section{Prejuízos à saúde e convivência familiar}

Chegamos a experimentar crack nos anos 1990, em um contexto de esgotamento das fontes fornecedoras de cocaina em pó, após certa hora da madrugada. Não pareceu fazer nenhum efeito digno de nota e a experiência não se repetiu. Nosso abandono do uso do álcool acompanhado de cocaína deu-se após período de internação em clínica de recuperação e frequência a reuniões dos Narcóticos Anônimos. Mais de 13 anos depois, novo contato com a substância. Qual o risco de tornar-se usuário pesado novamente? Dificil dizer. Há algo diferente no atual uso, significativo o suficiente para nos permitir ter esperanças de resultado diverso do uso anterior? Aparentemente, sim. O propósito de uso nos parece a maior diferença. Há o propósito claro em estar com eles e coletar dados; fazer uma etnografia, produzir uma tese de doutoramento em antropologia social, base para o início de uma carreira profissional como antropólogo, professor de antropologia, pesquisador.

Além de ter sido "adicto em recuperação" 47 sou asmático em tratamento. As incursões ao campo, respirar a fumaça, tragar, levaram a muito significativa piora dos sintomas. Iniciei tratamento ainda sem maiores resultados e uma série de medidas profiláticas no ambiente doméstico. Até onde prosseguir? "Não faça nada com que não possa conviver, profissionalmente e pessoalmente" (BERNARD, 2008, p. 376), este conselho dado

47 Termo usado pelos Narcóticos Anônimos àqueles em permanente busca por recuperar-se da compulsão e obsessão pelo uso de drogas. 
ao comportamento sexual no campo poderia servir também a outros limites do corpo do etnógrafo.

Do meu corpo, ao corpo dos outros e à convivência familiar. Fazer campo junto à população tão estigmatizada e em ambiente repleto de representações negativas construídas pela mídia constitui desafio ao convivio familiar. Na prática, é retornar ao lar, rever esposa e filha após estar sentado sobre chão coberto de urina, em meio a ratos, na companhia de traficantes e pessoas que realizam pequenos roubos. Ir dormir depois de vivenciar alguém lhe mostrar uma faca e, principalmente, chegar em casa com os olhos "esbugalhados" pela inalação da fumaça, ou pelo "trago". Isto tudo poderia ter tido maiores consequências para a minha vida conjugal e familiar, como foi para Bourgois após o final de sua pesquisa em El Barrio, que coincide com o fim de seu casamento. (BOURGOIS, 2006)

O problema ético insolúvel deste tipo de abordagem na opinião de Zinberg (1984), ao tratar em seu clássico Drug, set and setting do uso controlado de substâncias psicoativas como a heroína, é a possibilidade de nossas considerações levarem alguém a usar a droga e vir a ter problemas posteriores, esta preocupação parece caber de certa forma nesta pesquisa. ${ }^{48}$ Ele reconhece o modo como sua pesquisa acaba sendo posicionada no debate público a respeito das drogas e o problema ético. $\mathrm{Na}$ mídia e até em ambientes profissionais e por que não dizer acadêmicos também, o show precisa ser "balanceado", um entrevistado, ou palestrante pró-drogas e outro antidrogas. Estes, posicionados pela proibição e abstinência; qualquer oposição ao proibicionismo é percebida como pró-drogas. Mas, acima de tudo, existia um problema ético para Zinberg: declarar que algumas pessoas são capazes de controlar seu uso de heroína. Pois, é possivel que esta informação pudesse levar algum indi-

48 Para Zinberg, demonstrar o uso controlado, além de combater estereótipos, serviria à construção e reforço de outras possibilidades de uso, além do pesado. 
víduo a usar a droga, sem estar preparado devidamente e em condições de lidar com isso. ${ }^{49}$ Não tratamos especificamente de uso controlado de crack, como fez Zinberg com a heroína, nossa pesquisa busca, contudo, um ponto de vista fora dos estereótipos. Os usuários não são zumbis, são pessoas interessantes, inteligentes e devem ser respeitadas em sua opção de estilo de vida, este é o meu posicionamento. A objetividade vem do respeito ao bom método de coleta e análise de dados. O quanto isto poderia encorajar outros a fumar crack? Esta pergunta não tem resposta. Resta-nos apostar, como Zinberg, no reforço a padrões de quem usa sem se deixar usar pela droga, como é característico ouvir no discurso nativo.

49 Quando se verificou que o uso controlado era praticado por diversos usuários, percebeu-se que a descoberta tinha de vir ao conhecimento público, este deveria ser alertado do fato de o uso ocasional de heroína ser também um padrão estável, tanto quanto o abusivo. 